\title{
Penerapan Metode Drill untuk Meningkatkan Hasil Belajar Passing Bawah Bola Voli Siswa Kelas V Sekolah Dasar
}

\author{
Partini* \\ SD Negeri 1 Mlese Kecamatan Gantiwarno Kabupaten Klaten \\ *partini@gmail.com
}

\begin{abstract}
The purpose of this study was to find out the application of the drill method in improving the results of volleyball under-passing learning of fifth grade students of Mlese 1 Elementary School in Klaten Regency, Semester I 2018/2019 Academic Year. The research subjects consisted of 18 students. The instrument used to measure the success of teacher and student activities in teaching and learning activities is by using an observation sheet, while measuring student learning outcomes is a cognitive, affective and psychomotor test. This research was conducted in two cycles. The stages in this study follow the procedure of classroom action research, namely: (1) planning, (2) implementation of actions, (3) observations, and (4) reflection. From the results of the study concluded that the activities and learning outcomes of fifth grade students of SD Negeri 1 Mlese Gantiwarno District, Klaten Regency using the drill method showed maximum results, where in the first cycle the completeness level of teacher activities in carrying out learning activities only reached $72.72 \%$ and increased in cycle II to $100 \%$, for student learning completeness data $70 \%$ and experienced an increase in cycle II to $90 \%$, this has exceeded standards based on minimum completeness criteria of $85 \%$. While the learning outcomes of students in the first cycle only reached $66.67 \%$, increasing in the second cycle to $94.44 \%$ or have reached the level of learning completeness set by the school which is $80 \%$. Thus it can be concluded that the application of the drill method can improve the results of volleyball under-passing learning in grade $\mathrm{V}$ students of SD Negeri 1 Mlese Gantiwarno District, Klaten Regency, first semester of the school year 2018/2019.
\end{abstract}

\begin{abstract}
Abstrak: Tujuan penelitian ini adalah untuk mengetahui penerapkan metode drill dalam meningkatkan hasil belajar passing bawah bola voli siswa kelas V SD Negeri 1 Mlese Kabupaten Klaten Semester I Tahun Pelajaran 2018/ 2019. Subyek penelitian terdiri dari 18 siswa. Instrumen yang digunakan untuk mengukur keberhasilan aktivitas guru dan siswa dalam kegiatan belajar mengajar yakni dengan menggunakan lembar observasi, sedangkan untuk mengukur hasil belajar siswa adalah dengan tes kognitif, afektif dan psikomotor. Penelitian ini dilaksanakan dalam dua siklus. Tahapan dalam penelitian ini mengikuti prosedur penelitian tindakan kelas, yaitu: (1) perencanaan, (2) pelaksanaan tindakan, (3) pengamatan, dan (4) refleksi. Dari hasil penelitian diperoleh kesimpulan bahwa aktifitas dan hasil belajar siswa kelas V SD Negeri 1 Mlese Kecamatan Gantiwarno Kabupaten Klaten dengan menggunakan metode drill menunjukan hasil yang maksimal, dimana pada pada siklus I tingkat ketuntasan aktifitas guru dalam melaksanakan kegiatan pembelajaran baru mencapai $72,72 \%$ dan meningkat pada siklus II menjadi $100 \%$, untuk data ketuntasan belajar siswa $70 \%$ dan mengalami peningkatan pada siklus II menjadi $90 \%$, hal ini telah melebihi standar yang didasarkan kriteria ketuntasan minimal yakni $85 \%$. Sedangkan hasil belajar siswa pada siklus I baru mencapai $66,67 \%$ meningkat pada siklus II menjadi $94,44 \%$ atau telah mencapai tingkat ketuntasan belajar yang ditetapkan oleh sekolah yakni $80 \%$. Dengan demikian dapat disimpulkan bahwa penerapan metode drill dapat meningkatkan hasil belajar passing bawah bola voli siswa kelas V SD Negeri 1 Mlese Kecamatan Gantiwarno Kabupaten Klaten semester I tahun pelajaran 2018/2019.
\end{abstract}

Kata Kunci: metode drill, hasil belajar passing bawah, permainan bola voli. 


\section{Pendahuluan}

Tujuan Pendidikan Nasional menurut UU No. 20 tahun 2003 pasal 3 adalah mengembangkan potensi peserta didik supaya menjadi manusia yang beriman, bertaqwa kepada Tuhan Yang Maha Esa, berahklak mulia, sehat, berilmu, cakap, kreatif, mandiri dan menjadi warga negara yang demokrasi serta bertanggung jawab [1]. Ini merupakan tanggung jawab bersama khususnya guru untuk turut mencerdaskan bangsa, diantaranya melalui pendidikan formal mulai dari sekolah dasar sampai perguruan tinggi. kegiatan belajar merupakan kegiatan yang amat komplek bukan saja menyangkut aspek kejiwaan tetapi juga aspek fisik, maka guru harus berupaya semaksimal mungkin dalam menata lingkungan belajar dan perencanaan materi pembelajaran yang matang agar terjadi proses pembelajaran yang efektif baik itu didalam maupun diluar kelas guru harus mengenal substansi yang dipelajari menyangkut aspek kognitif, afektif dan psikomotor.

Pendidikan jasmani adalah proses pendidikan yang menyeluruh yang menggunakan aktivitas fisik dengan permainan dan olahraga sebagai alatnya [2]. Dengan demikian dapat diduga dengan muda bahwa tujuannya bukan sekedar pencapaian yang bersifat fisik semata, akan tetapi juga melibatkan aktivitas psikis. Program pengajaran pendidikan jasmani memiliki 6 jenis ruang lingkup yaitu : (1) aktivitas permainan dan olahraga, (2) aktivitas pengembangan, (3) aktivitas uji diri, (4) aktivitas ritmik, (5) aktifitas air, dan (6) aktifitas luar sekolah/alam bebas. Seluruh jenis aktivitas tersebut diharapkan dapat dilaksanakan oleh sekolah, namun jika di sekolah atau disekitar tidak terdapat sarana dan prasarana penunjang, maka aktivitas tersebut dapat diganti dengan aktifitas fisik lain yang memungkinkan dapat dilaksanakan disekolah. Pendidikan jasmani di sekolah mempunyai tujuan selain untuk meningkatkan kesegaran jasmani juga untuk membentuk nilai kognitif (pengetahuan), afektif (sikap) dan psikomotor (gerak) peserta didik. Dalam pendidikan jasmani terdiri atas beberapa permainan atau olahraga, salah satunya adalah permainan bola voli.

Bola voli merupakan suatu permainan beregu yang dimainkan oleh dua tim yang saling berhadapan dan masing-masing terdiri dari enam pemain. Permainan bola voli sangat terkenal dimasyarakat, dimulai dari kalangan atas sampai kalangan bawah sudah tidak asing lagi dengan nama permainan bola voli. Sering dijumpai didaerah-daerah tertentu permainan bola voli ini dimainkan oleh banyak orang mulai dari anak-anak sampai dewasa. Kebanyakan orang memainkan bola voli ini untuk mengisi waktu luang, mencari keringat, dan bahkan untuk meningkatkan prestasi. Permainan bola voli adalah memainkan bola dengan net dan menjatuhkan bola di dalam lapangan permainan lawan dengan menyeberangkan bola melewati jaring dan mempertahankan bola agar tidak jatuh di bidang permainan sendiri [3].

Manfaat dari bermain bola voli adalah: 1) kerja sama, 2) kecepatan bergerak, dan 3) lompatan yang tinggi untuk mengatasi bola yang berada diatas net [4]. Oleh karena itu permainan memerlukan fisik yang baik, postur tubuh yang tinggi dan atletis, sehat, terampil, cerdas dan sikap sosial yang tinggi agar dapat menjadi pemain yang berbobot baik dan dapat dikatakan sebagai pemain yang handal profesional. Permainan bola voli memiliki aturan-aturan yang harus diketahui yaitu:

a. Sistem hitungan yang digunakan adalah 25 rally point. Bila poin peserta seri (24-24) maka pertandingan akan ditambah 2 poin. Peserta yg pertama kali unggul dengan selisih 2 poin akan memenangi pertandingan.

b. Pada saat servis bola yang melewati lapangan dihitung sebagai poin bagi lawan, begitu juga sebaliknya penerima servis lawan yang membuat bola keluar dihitung sebagai poin bagi lawan.

c. Seluruh pemain harus berada di dalam lapangan pada saat servis dilakukan.

d. Bola servis menyentuh net tetapi masuk ke daerah lawan dianggap sah.

e. Kesalahan meliputi :

1) Pemain menyentuh net atau melewati garis batas tengah lapangan lawan.

2) Tidak boleh melempar ataupun menangkap bola. Bola volley harus di pantulkan tanpa mengenai dasar lapangan

Permainan bola voli terdiri atas beberapa teknik, diantaranya teknik dengan menggunakan bola yang meliputi servis, passing bawah, passing atas, umpan, smash, dan block [4]. Pasing merupakan salah satu teknik dalam permainan bola voli, yang jika ditinjau dari segi taktik sudah 
merupakan suatu serangan awal untuk memperoleh nilai agar suatu regu berhasil meraih kemenangan [5]. Passing harus dilakukan dengan baik dan 3 sempurna oleh semua pemain karena kesalahan pemain mengakibatkan pertambahan angka dari lawan. Demikian pentingnya kedudukan passing dalam permainan bola voli maka passing harus dilakukan dengan baik, oleh karena itu passing harus terarah dan terukur dengan tujuan agar kawan yang berposisi sebagai spiker mudah melakukan spike yang akurat.

Teknik melakukan passing bermacam-macam menurut Suharno ada dua macam pukulan passing yang dikenal dan sering dimainkan yaitu passing atas dan passing bawah [6]. Passing bawah adalah passing yang sering digunakan oleh pemain pemula karena jenis passing ini merupakan passing yang sangat sederhana dan mudah. Gerakan passing bawah lebih alamiah dan tenaga yang dibutuhkan tidak terlalu besar [5]. Passing bawah ini sesuai diajarkan terutama untuk pemain yang masih dalam taraf berlatih/belajar seperti anak sekolah. Hal tersebut sesuai dengan pernyataan Herry Koesyanto (2003), bahwa bagi pemain pemula cara akan lebih mudah untuk mempelajari passing bawah karena tenaga yang dibutuhkan tidak terlalu besar sehingga dalam waktu yang singkat sudah dapat menguasai [7].

Prestasi belajar adalah hasil belajar dari suatu individu tersebut berinteraksi secara aktif dan pasif dengan lingkungannya. Berkaitan dengan hasil belajar yang di peroleh, terdapat tipe hasil belajar menurut Sudjana (2004), yaitu [8]:

a. Tipe hasil belajar kognitif meliputi pengetahuan, pemahaman, penerapan, analisis sintesis, dan evaluasi.

b. Tipe hasil belajar bidang afektif meliputi penerimaan, jawaban, penilaian, organisir, dan karakteristik nilai.

c. Tipe hasil belajar bidang psikomotor meliputi tingkatan keterampilan.

Teknik dasar adalah cara melakukan sesuatu untuk mencapai tujuan tertentu secara efektif sesuai dengan peraturan yang berlaku untuk mencapai hasil yang optimal, Horsono (1988). Jadi untuk mengembangkan dan memenangkan sesuatu diperlukan teknik dan taktik yang benar. Teknik dasar permainan bola voli selalu berkembang sesuai dengan perkembangan pengetehuan dan teknologi dan ilmu-ilmu lain. Adapun teknik-teknik dalam permainan dalam bola voli meliputi : (1) service (2) passing (3) umpan (4) smash(5) bendungan [5]. Dalam penelitian ini yang menjadi fokus permasalahan adalah teknik dasar passing, sehingga yang menjadi penekanan pada kajiannya adalah pada teknik passing saja.

Passing dan umpan dapat dilakukan dengan dua cara yaitu dari bawah dan dari atas. Passing bawah digunanakan apabila bola yang datang dibawah 9 ketinggian dada, [9]. Cara melakukan teknik passing bawah dan passing atas sangat berbeda. Pada umumnya passing bawah tidak melibatkan jari-jari, akan tetapi bola menyentuh bagian dan pergelangan tangan, biasanya dilakukan dengan satu atau dua tangan. Sedangkan passing dan umpan dari atas pada umumnya melibatkan jari-jari tangan.

Passing atau peran lengan bawah merupakan satu rangkayan melakukan operan dengan lengang bawah yang terdiri dari : (1) sikap awal; (2) pelaksanaan; (3) gerak lanjutan [10]. Sikap awal, kedua kaki dibuka selebar bahu, salah satu kaki berada di depan, lutut ditekuk dengan togok dibungkukkan. Pandangan mengikuti gerakan pemain lawan dan gerak datangnya bola. Kedua tangan berada diantara bahu dan lutut, tubuh rileks. Berat badan pada telapak kaki bagian depan. Posisi tangan yang menyerupai mangkok direkomendasikan karena pada umumnya posisi ini merupakan bentuk yang paling menguntungkan dan memungkinkan pemain untuk membentuk bidang yang sejajar dengan permukaan lengan bawah yang rata. Cara ini membantu memastikan bola melambung ke sasaran dengan normal. Pada saat kontak dengan bola, pinggang tetap sedikit dibungkukkan dan lutut dilenturkan, memindahkan berat badan menjadi agak maju ke arah bola atau melangkah sedikit ke arah sasaran dengan kaki yang berada di depan untuk mulai.

Pelaksanaan, bergerak ke arah bola dan mengatur posisi tubuh, kedua jari tangan saling menggenggam. Siku diputar sehingga bagian lengan yang datar menghadap ke atas. Tangan sejajar dengan paha. Bola di arahkan dengan tubuh, melalui gerakan mengulurkan kaki sambil mengayunkan lengan. Perkenaan pukulan bola harus jauh dari tubuh, pandangan selalu kearah bola. 
Gerakan lanjutan, setelah bola dipukul kedua jari tetap tergenggam. Siku tatap terkunci, lengan sejajar berada dibawah bahuPembelajaran bola voli siswa dapat belajar bergerak dan belajar melalui gerak [2]. Belajar bergerak menekankan pada kemampuan siswa untuk dapat melakukan gerakan-gerakan dalam permainan bola voli. Nilai-nilai luhur yang terkandung yaitu kerja sama, toleransi, kejujuran, saling menghargai, menghormati, disiplin dan sebagainya. Dalam hal ini diperlukan metode mengajar yang tepat, karena dengan penerapan metode yang tepat bagi anak didik memberikan hasil pengajaran yang diperoleh dapat membuahkan hasil berupa 4 keterampilan bermain yang optimal terutama untuk pembelajaran bola voli di sekolah.

Berdasarkan kenyataan dilapangan bahwa kemampuan passing bawah tingkat SD khususnya siswa kelas V SD Negeri 1 Japanan Cawas Klaten semester II tahun pelajaran 2017/2018 masih rendah yakni dari 18 siswa hanya 8 orang yang mencapai nilai kriteria ketuntasan minimal (KKM). Hal ini dibuktikan dengan banyak diantara peserta didik yang belum mampu melakukan passing bawah secara sempurna. Salah satu penyebab utama kegagalan dari proses pembelajaran adalah penerapan metode pembelajaran yang konvesional yakni lebih menekankan pada dominasi peran guru. Hal ini berdampak pada ketidak seriusan dan rasa bosan mengikuti proses pembelajaran. Berdasarkan pada kondisi tersebut, maka peneliti mencoba untuk menerapkan pembelajaran dengan menggunakan metode metode drill.

Amung Ma'mum dan Toto Subroto menyatakan metode drill adalah cara belajar yang lebih menekankan penguasaan komponen-komponen teknik dan mengulangi yang telah dipelajari sebelumnya [9]. Rusli Lutan menyatakan bahwa keaktifan sendiri dari pihak siswa merupakan kunci utama penguasaan dan pemantapan gerak, kelangsungan proses latihan pada tahap berikutnya ialah penguasaan teknik yang ideal [2]. Hal ini tergantung pada inisiatif dari siswa itu sendiri, sedangkan guru bertugas mengarahkan penguasaan gerak, melakukan koreksi dan evaluasi setiap terjadi kesalahan teknik agar terhindar dari pola gerakan yang salah dari teknik yang dipelajari. Dapat disimpulkan bawah metode drill merupakan pembelajaran yang menekankan pada penguasaan teknik suatu 19 cabang olahraga yang dalam pelaksanaannya dilakukan secara berulang-ulang. Dalam hal ini pembelajaran yang dilaksanakan secara berulang-ulang tidak keluar dari suatu gerakan teknik dasar yang ingin ditingkatkan yaitu teknik passing bawah.

Keunggulan menggunakan metode drill adalah peserta didik memperoleh ketangkasan dan kemahiran dalam melakukan suatu gerakan sesuai dengan apa yang dipelajarinya, akan menimbulkan rasa percaya diri peserta didik yang berhasil dalam belajar, karena telah memiliki keterampilan khusus yang akan berguna dikemudian hari. Dan guru akan lebih muda mengontrol dan membedakan mana peserta didik yang disiplin, dengan memperhatikan tindakan dan perbuatan peserta didik saat berlangsungnya proses belajar mengajar, [11].

Berdasarkan latar belakang yang telah disampaikan di atas, tujuan penelitian ini adalah untuk mengetahui penerapkan metode drill dalam meningkatkan hasil belajar passing bawah bola voli siswa kelas V SD Negeri 1 Mlese Kecamatan Gantiwarno Kabupaten Klaten Semester I Tahun Pelajaran 2018/ 2019..

\section{Metode Penelitian}

Penelitian ini termasuk penelitian tindakan kelas (classroom action research). Dalam penelitian tindakan kelas ini, ada tindakan (aksi) tertentu untuk meningkatkan hasil belajar passing bawah bola voli siswa kelas V SD Negeri 1 Mlese Kecamatan Gantiwarno Kabupaten Klaten Semester I Tahun Pelajaran 2018/ 2019 dengan menggunakan metode drill.

Penelitian ini akan dilaksanakan di SD Negeri 1 Mlese Gantiwarno Klaten dengan subyek penelitian adalah seluruh siswa kelas V semester I tahun pelajaran 2018/2019. Pelaksanaan penelitian direncanakan pada semester I tahun pelajaran 2018/2019 selama 2 bulan dengan direncanakan mulai dari September sampai dengan Oktober 2018 dengan menyesuaikan jam pelajaran olahraga kelas tersebut.

Data yang diperoleh adalah data kuantitatif dan kualitatif, data kuantitatif diambil dari tes hasil belajar siswa sedangkan data kualitatif diambil dari hasil observasi guru dan siswa kelas V SD Negeri 1 Mlese. 
Teknik pengumpulan data dalam penelitian tindakan kelas ini terdiri dari tes unjuk kerja dan observasi.

1. Tes unjuk kerja digunakan untuk mendapatkan data tentang hasil teknik dasar passing bawah bola voli yang dilakukan oleh siswa dan tes yang digunakan dalam bentuk uraian.

2. Lembar observasi, di pergunakan sebagai teknik mengumpulkan data tentang aktifitas guru dan siswa selama kegiatan belajar mengajar bola voli yang berfungsi untuk mengetahui adanya keserasian antara perencanaan tindakan, pelaksanaan tindakan dan untuk mengetahui sejauh mana dapat menghasilkan perubahan yang diinginkan oleh peneliti

Adapun langkah-langkah pelaksanaan PTK secara prosedurnya adalah dilaksanakan secara partisipatif atau kolaborasi (guru, dengan tim lainnya) bekerja sama, mulai dari tahap orientasi dilanjutkan penyusunan rencana tindakan, dilanjutkan pelaksanaan tindakan dalam siklus pertama. Diskusi yang bersifat analitik yang kemudian dilanjutkan pada langkah reflektif-evaluatif atas kegiatan yang dilakukan pada siklus pertama, untuk kemudian mempersiapkan rencana modifikasi, koreksi, atau pembetulan, atau penyempurnaan pada siklus kedua dan seterusnya.

Indikator keberhasilan dalam penelitian tindakan kelas ini adalah apabila ketuntasan aktivitas guru dan siswa mencapai $85 \%$ dari seluruh indikator dan hasil belajar siswa yang memperoleh nilai 70 sudah mencapai $75 \%$ dari jumlah siswa, maka penelitian ini dikatakan tuntas berdasarkan Kriterai Ketuntasan Minimal ( KKM ) dari sekolah.

\section{Hasil dan Pembahasan}

\section{a. Hasil Penelitian}

1) Deskripsi Aktivitas Siswa Selama Kegiatan Belajar Mengajar (KBM) Berlangsung

Pada siklus I jumlah indikator yang terlaksana $(\mathrm{Ya})=7$ indikator, sedangkan pada siklus II jumlah indikator yang terlaksana $(\mathrm{Ya})=9$ indikator. Jika keterlaksanaan indikator tersebut dipersentasekan, maka pada siklus I indikator yang terlaksana hanya sebesar $70 \%$ sedangkan pada siklus II indikator yang terlaksana 90\%. Dapat diketahui bahwa kriteria ketuntasan aktifitas siswa pada siklus II telah tercapai sesuai dengan ketuntasan belajar yang diinginkan.

2) Deskripsi Aktivitas Guru Selama Kegiatan Belajar Mengajar (KBM) Berlangsung

Aktifitas guru selama kegiatan belajar mengajar (KBM) berlangsung dengan indikator yang terlaksana (Ya) pada siklus I sebanyak 8 indikator, sedangkan pada siklus II indikator yang terlaksana mencapai 11 indikator, sementara itu persentase keterlaksanaan pada siklus I sebesar 72,72\%dan pada siklus II persentase keterlaksanaan mencapai $100 \%$. Dengan demikian diperoleh hasil persentase yang menerangkan bahwa pada siklus I tidak mencapai ketuntasan dan pada siklus II telah mencapai ketuntasan.

3) Deskripsi Hasil Belajar

Tabel 1. Persentase Ketuntasan Hasil Belajar Siswa siklus I dan Siklus II

\begin{tabular}{lllll}
\hline \multirow{2}{*}{ Hasil Belajar } & \multicolumn{2}{l}{ Siklus I } & \multicolumn{2}{l}{ Siklus II } \\
\cline { 2 - 5 } & $\mathbf{\Sigma}$ & $\%$ & $\mathbf{\Sigma}$ & $\%$ \\
\hline Tuntas & 12 & $66,67 \%$ & 17 & 94,44 \\
& & & & $\%$ \\
Tidak Tuntas & 6 & $33,33 \%$ & 1 & $5,56 \%$ \\
\hline $\begin{array}{l}\text { Peningkatan persentase } \\
\text { hasil belajar tiap siklus }\end{array}$ & $\mathbf{6 6 , 6 7} \%$ & $\mathbf{9 4 , 4 4} \%$ \\
\hline
\end{tabular}

Berdasarkan analisis data hasil penilaian formatif menunjukan bahwa pada siklus I siswa yang tuntas hasil belajarnya sebanyak 12 orang atau $66,67 \%$ dan yang belajarnya 
belum tuntas sebanyak 6 orang atau 33,33\%. Sedangkan pada siklus II siswa yang tuntas hasil belajarnya sebanyak 17 orang atau $94,44 \%$ dan yang tidak tuntas sebanyak 1 orang atau $5,56 \%$. Jadi ketuntasan belajar siswa kelas V SD Negeri 1 Mlese pada siklus II telah mencapai tingkat ketuntasan belajar yang ditetapkan oleh pihak sekolah yaitu minimal $80 \%$ siswa memperoleh nilai 70 .

\section{b. Pembahasan}

Frekuensi aktifitas siswa pada siklus I menunjukan siswa kurang maksimal dalam mengikuti pembelajaran dengan menggunakan metode drill dimana seluruh indikator aktifitas siswa tidak sepenuhnya terlaksanakan. Sedangkan pada siklus II hampir seluruh indikator aktifitas siswa telah dilaksanakan, diantaranya :

1. Siswa terampil dalam melakukan passing bawah dalam pembelajaran bola voli.

2. Siswa bekerja sama dalam melaksanakan kegiatan passing bawah.

3. Mempraktikan materi sesuai dengan bagian-bagian atau fase gerakan passing bawah.

Untuk mengatasi rendahnya aktifitas siswa pada pertemuan pertama siklus I, guru mata pelajaran bersama peneliti melakukan analisis dan refleksi terhadap faktor-faktor yang menyebabkan rendahnya aktifitas siswa maupun aktifitas guru dalam pembelajaran dan disepakati adanya beberapa kelemahan dalam mengelola pembelajaran, yakni:

a. Guru tidak memotifasi dan menjelaskan tujuan pembelajaran

b. Guru tidak merangsang peserta didik untuk bertanya mengenai hal-hal yang belum dipahami tentang pokok bahasan passing bawah.

c. Guru kurang memberikan umpan balik terhadap siswa yang melakukan gerakan passing bawah.

d. Guru kurang mengorganisasi, dalam hal ini mengarahkan siswa untuk mempelajari materi passing bawah yang telah diberikanserta mengarahkan siswa untuk selalu bekerja sama dan sunguh-sungguh dalam melaksanakan kegiatan pembelajaran.

e. Guru tidak memperhatikan waktu dalam proses pembelajaran dengan baik, sehingga terkesan bahwa pembelajaran tidak efektif dan tidak sesuai dengan waktu yang direncanakan.

Hasil refleksi siklus I kemudian ditentukan langkah-langkah perbaikan untuk siklus II, yakni sebagai berikut :

a. Guru hendaknya senantiasa memotivasi siswa supaya siswa antusias dalam belajar dan menjelaskan tujuan pembelajaran sehingga siswa memiliki rasa tanggung jawab untuk melaksanakanya.

b. Guru hendaknya merangsang peserta didik untuk bertanya tentang hal-hal yang belum dipahami sekaligus membimbing mereka agar permasalahan siswa dapat terselesaikan.

c. Guru selalu memberikan umpan balik terhadap hasil kegiatan belajar siswa serta mengarahkan siswa tentang cara melaksanakan gerakan passing bawah dengan benar.

d. Guru bersama peneliti berkolaborasi dalam mengatur waktu.

Adapun aktifitas siswa yang diperoleh dari hasil pengamatan pada siklus II adalah :

1. Mendengarkan dan memperhatikan penjelasan guru mengenai materi passing bawah Pada siklus II ini para siswa sangat antusias mendengarkan dan memperhatikan penjelasan guru mengenai tahapan-tahapan rangkaian gerak teknik dasar passing bawah.

2. Mengajukan pertanyaan kepada siswa/guru

Pada siklus ini para siswa sangat antusias dengan materi yang diberikan dan partisipasi siswa untuk mengikuti pelajaran sangat tinggi, para siswa sudah berani mengajukan pertanyaan mengenai pokok bahasan passing bawah yang mereka belum pahami.

3. Siswa terampil dalam mengulangi setiap gerakan pembelajaran passing bawah

Pada siklus ini seluruh siswa menunjukan keseriusan melakukan gerakan passing bawah secara berulang-ulang dan mereka selalu menanyakan mengenai fase gerakan yang belum dipahaminya.

4. Bertanggung jawab atas ketuntasan materi passing bawah 
Para siswa sudah mampu memahami materi yang diberikan sehingga dengan pemahaman ini siswa sudah mampu menjawab dan memperagakan fase gerakan passing bawah sesuai yang dijelaskan dan diperagakan oleh guru.

5. Memperagakan gerakan passing bawah secara mandiri

Pada siklus II ini siswa sangat antusias dan percaya diri memperagakan fase gerakan teknik passing bawah secara mandiri, tetapi guru tetap berperan memberikan bantuan jika siswa mengalami kesulitan.

6. Bekerja sama dalam melaksanakan kegiatan belajar passing bawah

Pada kegiatan ini seluruh siswa sangat bersungguh-sungguh mengikuti proses belajar, mereka saling membantu dalam melakukan rangkaian gerak passing bawah.

7. Malaksanakan kegiatan pembelajaran passing bawah

Pada siklus II ini seluruh siswa sangat antusias dan untuk melaksanakan rangkaian gerak passing bawah sesuai dengan kemampuannya masing-masing sehingga setiap siswa termotivasi untuk manjadikan dirinya yang terbaik dalam melakukan passing bawah.

Analisis deskriptif ketuntasan hasil belajar siswa pada siklus II dengan pokok bahasan passing bawah yang memperoleh nilai $>70$ atau kategori tuntas sebanyak 17 orang atau 94,44\% dan siswa yang memperoleh nilai $<70$ sebanyak 1 orang atau 5,56\%. Ini menunjukan bahwa indikator keberhasilan siklus II sebesar $80 \%$ siswa memperoleh nilai > 70 sudah tercapai dan tidak dilanjutkan ke siklus berikutnnya.

Ketuntasan hasil belajar yang dicapai oleh siswa tidak hanya dipengaruhi oleh model pembelajaran yang diterapkan oleh guru. Akan tetapi ada faktor lain yang mempengaruhinya yaitu faktor internal dan faktor eksternal. Faktor internal yaitu segala sesuatu yang berhubungan dengan diri pribadi siswa seperti faktor fisik dan faktor psikologi/mental. Sedangkan faktor eksternal yaitu segala sesuatu diluar pribadi siswa seperti faktor sosial, faktor budaya dan lingkungan[12].

\section{Kesimpulan}

Hasil penelitian ini dapat disimpulkan sebagai berikut :

1. Aktifitas dan hasil belajar siswa kelas VII B SMP Negeri 2 Cawas dengan menggunakan metode drill menunjukan hasil yang maksimal, dimana Pada pada siklus I tingkat ketuntasan aktifitas guru dalam melaksanakan kegiatan pembelajaran baru mencapai 72,72\% dan meningkat pada siklus II menjadi $100 \%$, untuk data ketuntasan belajar siswa $70 \%$ dan mengalami peningkatan pada siklus II menjadi 90\%, hal ini telah melebihi standar yang didasarkan kriteria ketuntasan minimal yakni $85 \%$. Sedangkan hasil belajar siswa pada siklus I baru mencapai $65,22 \%$ meningkat pada siklus II menjadi $91,30 \%$ atau telah mencapai tingkat ketuntasan belajar yang ditetapkan oleh sekolah yakni $75 \%$.

2. Penerapan metode drill dapat meningkatkan hasil belajar passing bawah bola voli pada siswa kelas VII B SMP Negeri 2 Cawas. Hal ini ditunjang oleh fakta bahwa baik tingkat ketuntasan aktivitas guru dan siswa dalam melaksanakan kegiatan belajar mengajar maupun hasil belajar siswa, telah melampauhi batas ketuntasan belajar yang ditetapkan oleh pihak sekolah.

\section{References}

[1] Depdikdas Depdiknas. 2003. Undang-undang Nomor 23 tahun 2003 tentang Sistem Pendidikan Nasional. Jakarta: Depdiknas.

[2] Lutan, Rusli. 2001. Pendidikan Kebugaran Jasmani. Depdiknas: Jakarta.

[3] Sukintaka. 1983. Permainan Bola Voli. Jakarta: Depdikbud.

[4] Suharno. 1984. Teknik Permainan Bola Voli. Bandung: Arkola

[5] Yunus, M. 1992. Olahraga Pilihan Bola Voli. Jakarta: Depdikbud Dirjen Dikti

[6] Suharno. 1979. Dasar-dasar Permainan Bola Voli. Yogyakarta: Kaliwangi.

[7] Koesyanto, Herry. 2003. Belajar Bermain Bola Volley. Semarang: FIK UNNES.

[8] Sudjana. 2004. Teori-Teori Pembelajaran untuk Pengajaran. Jakarta: UT 
[9] Ma'mum, Amung \& Toto Subroto. 2001. Pendekatan Keterampilan Taktis Dalam Pembelajaran. Jakarta: Dirjen Dikdasmen

[10] Ahmadi, Nuril. 2007. Panduan Olahraga Bola Voli. Solo : Era Pustaka Utama.

[11] Http://harjasapoetra.blogspot.co.id/2010/03.metode-latihan-drill-metodologi-html

[12] Uzer, Usman. 1993. Upaya Optimalisasi kegiatan Belajar mengajar Baha Kajian PKG, MKBS, $M G M P$. Bandung: PT Remaja Resdakarya. 